DOI: https://doi.org/10.18485/fb_iss.2020.1.ch6

\title{
ДОМЕТИ ПРЕДИКЦИЈЕ У СТРАТЕШКИМ СТУДИЈАМА: ЗНАЧАЈ ЕКСПЕРТСКОГ ЗНАЊА И АЛАТА ВЕШТАЧКЕ ИНТЕЛИГЕНЦИЈЕ
}

\author{
мср Ненад Стекић ${ }^{1}$
}

\begin{abstract}
Апстракт
У научно-сазнајном смислу, предвиђање појава као један од научних циљева у већини случајева је релативно недостижна активност. Ограничења предикције нарочито бивају изражена у проучавању друштвених појава чија се феноменологија карактерише високим степеном променљивости и неправилности. Ширење истраживачке агенде стратешких студија намеће потребу за све учесталијим сложеним анализама са задатком да пруже могуће обрисе развоја појединих догађаја или процеса у будућности. Предмет проучавања стратешких студија је стога природно временски усмерен на актуелну стварност и догађаје у будућности. Овај рад има за циљ да прикаже две групе алата који су на располагању истраживачима у предикцији појава у оквиру стратешких студија. Како је у литератури стратешких студија предвиђање могућег нарушавања војне безбедности избијањем оружаних сукоба идентификовано као најзначајнији задатак, предмет овог рада обухвата приказ две групе техника за анализу и предвиђање оружаних сукоба: експертског знања и вештачке интелигенције. Сваку од група техника карактеришу специфичности и ограничења у извођењу предиктивних ставова. Аутор ће упутити на домете техника за предикцију базираних на знању експерата - делфи техника, док ће у оквиру алата вештачке интелигенције бити представљене могућности анализе које произилазе из процеса машинског учења (Machine Learning) и неуралних мрежа (Neural Networks). Иако су подаци и информатички алати несумњиво доминантни у иновирању начина анализе прошлих и предвиђања будућих појава, не треба занемаривати значај експертског знања добијеног на бази групног одлучивања.
\end{abstract}

Кључне речи: стратешке студије, делфи техника, машинско учење, неуралне мреже, вештачка интелигенција, предикција, оружани сукоби

\footnotetext{
1 Истраживач сарадник, Институт за међународну политику и привреду, Београд. Е-пошта: nenad.stekic@diplomacy.bg.ac.rs

Рад је настао у оквиру пројекта „Србија и изазови у међународним односима 2020. године“, који финансира Министарство просвете, науке и технолошког развоја Републике Србије, а реализује Институт за међународну политику и привреду током 2020. године.
} 


\section{НИВОИ ПРЕДВИЪАҢА ЗА ИЗАЗОВЕ САВРЕМЕНОГ СВЕТА}

Оно што омогућава паметном суверену и добром генералу да напада, осваја и остварује циљеве изван домашаја обичног човека, јесте предзнање. ${ }^{2}$ Предвиђање појава је од давнина окупирало пажњу људи. Развојем рудиментарних друштвено-политичких заједница и настанком првих сложенијих облика организације друштва, нарасле су потребе за предвиђањем онога што би се могло догодити у блиској будућности, а што би олакшало доношење одлука. Предвиђања олакшавају свакодневни живот, али посебан значај имају у великом броју научних дисциплина, где се јављају као један од могућих циљева истраживања. Предмет научно засноване предикције природно зависи од дисциплине чији се домен проучавања истражује. Релативно консензуалан је став да предмет стратешких студија чини употреба силе у промоцији и остваривању општијих спољнополитичких циљева од стране држава и других политичких актера. ${ }^{3}$ Овакво одређење предмета стратешких студија Роберта Ајсона (Robert Ayson) не идентификује у потпуности „друге политичке актере“. На бази пресека стања у савременом систему међународних односа може се претпоставити да су „недржавни“ актери заправо војни савези и међународне организације које имају капацитет за употребу силе. Оног тренутка кад ниво интеракција између држава достигне критичну тачку у погледу заоштравања односа и могуће ескалације оружаног сукоба, тада њихови односи постају предмет стратешких студија. Ајсен делимично оспорава овакво виђење, сматрајући да се предмет стратешких студија протеже и на порекло, примену и импликације организованог насиља у времену рата, али и мира. ${ }^{4}$ Делимичном сужавању предмета проучавања стратешких студија допринео је Хедли Бул (Hedley Bull), који је исправно приметио да је у „хладноратовској ери стратешко померено са рата као инструмента свакодневне политике на претњу ратом“.5 Бул посматра стратегију као „...науку обликовања средстава зарад промоције циљева у било којој врсти конфликта".6

Како домен проучавања стратешких студија обухвата сложену мрежу међудржавних односа и њиховог коришћења силе, јасно је да постоји изражена неопходност прегледа и развоја метода којима се пружају прогнозе „понашања“ држава у међународном систему. Постоје два нивоа на којима предикција може бити аплицирана у стратешким студијама: као метанаратив ове научне дисциплине (са ограничењима њеног сазнајног домета), али је могуће говорити и о предикцији у стратешким студијама. У том случају анализира се скуп метода

\footnotetext{
2 Sun Tzu, "The Art of War", Allandale Online Publishing, United Kingdom, 2000, p. 59.

3 Видети више у: Ayson, Robert, "Strategic Studies", in: Christian Reus-Smit and Duncan Snidal (eds.) "The Oxford Handbook of International Relations", 2008, p. 558.

4 Ibid., p. 559.

5 Bull, Hedley, "Strategic Studies and its Critics", World Politics, Vol. 20, No. 4, (July 1968), pp. 593-605.

6 Ibid., p. 593.
} 
којима се остварује научни циљ - предикција у оквиру домена оивиченог истраживаним појавама које чине предмет проучавања стратешких студија.

У савременој литератури не постоји јасна дистинкција између такозваних нивоа предвиђања. Мада се често изједначавају, нивои предвиђања нису истоветни. Свако (са)знање о догађају или процесу који ће се десити је предвиђање. Међутим, таква свест може бити утемељена на различитим основама, при чему је најригорознија научна предикција, која се јавља као један од могућих циљева научних истраживања. На вертикали „ригорозности“ лаичко предвиђање се налази на самом дну. Оваква врста предвиђања проистиче из личног искуства, а ређе се може изводити из професионалног (експертског) искуства. На вишем нивоу предвиђања јавља се прогнозирање (forecast), које представља пружање увида у могућ развој догађаја и/или процеса који треба да наступе у будућности, а базирано је на јасно прецизираним правилима и дефинисаним постулатима. У свакој области за коју се дају прогнозе такви исходи су веома структурисани и продукт су низа фактора и индикатора. Због тога свако прогнозирање карактерише нешто виши степен извора на којима почива од простог, лаичког предвиђања.

Прогнозирање продукује могућу свест о потенцијалном наступању појаве и изазива предзнање (foreknowledge) о њој. Сврха прогнозирања јесте упознавање шире заједнице (академске, стручне или лаичке) са могућим испољавањем појаве и њеним интензитетом, односно ширење предзнања о одређеном скупу појава које су од значаја за свакодневни живот људи или опстанак државе. Када се предзнање (продуковано на бази прецизно дефинисаних индикатора и техника) контекстуализује тако да унапређује постојећи фонд знања у научној дисциплини, тада се може говорити о предикцији као научном циљу. Због највишег степена структурисаности и захтевима у погледу научно заснованог стицања предзнања о појединим појавама, научна предикција се на скали „ригорозности“ налази на највишем месту.

Циљ овог рада је приказ техника помоћу којих је могуће остварити предикцију догађаја који могу пресудно утицати на развој света у 21. веку, као и на стратешко понашање држава. Приказ ће се фокусирати на два, наизглед супротстављена метода, чији је апликативни и научни потенцијал изузетно висок: консензус експерата (делфи техника) и алате вештачке интелигенције (машинско учење и неуралне мреже).

Структура овог рада организована је тако да представи концепт предвиђања, затим предикцију као научни циљ и моделе предвиђања уопште, са фокусом на употребну вредност у домену стратешких студија. Централни део чланка заузимају прегледи о обележјима, начинима спровођења, могућностима уопштавања добијених налаза који се односе на делфи технику. Додатно, представљена је логика и начин аплицирања машинског учења и неуронских мрежа као алата вештачке интелигенције у процесирању велике количине података који се не могу адекватно анализирати „класичном“ употребом статистичких метода. Аутор указује на предиктивну валидност и ограничења 
наведених метода, са дискусијом која је усмерена на идентификацију њихове примене у проучавањима развоја будућих појава у домену стратешких студија.

\section{ПРЕДВИЪАЊЕ ЗАСНОВАНО НА ЕКСПЕРТСКОМ ЗНАҢУ - ДЕЛФИ ТЕХНИКА}

До развоја модерних рачунара извори предикције долазили су искључиво из корпуса људског знања. Сун Цу (Sun Tzu) је у свом капиталном делу „Умеће ратовања“ указао да се предзнање о некој појави не може добити искуствено нити дедуктивним прорачуном, већ се знање о непријатељу стиче само од других људи. ${ }^{7}$ Наравно, у савременој дигиталној ери, извори података за предикцију потичу из мноштва систематизованих сетова података - кодификованих записа о оружаним конфликтима, типовима политичких режима и сл., о чему ће речи бити у другом поглављу.

Техника делфи (eng. Delphi technique) представља посебан вид групног консензуалног одлучивања експерата у вези са питањем које је у домену њихове експертизе. Иницијално је развијена у оквиру корпорације РАНД (RAND Corporation) средином прошлог века за потребе предикције утицаја тадашње технологије на ратовање. ${ }^{8}$ Првобитно зацртан циљ овој техници односио се на „смањење распона у одговорима и постизање експертског консензуса“.9 У каснијим фазама њеног усавршавања, делфи техника је из сфере војне безбедности убрзо своје место пронашла и у цивилној сфери даљом научном систематизацијом и првим академским напорима за њеним аплицирањем у изучавању појава безбедности. Логика делфи метода базирана је на комбиновању појединачних стручних ставова који доводе до креирања преференци групе, чији су налази, идеално говорећи, квалитетнији чак и од појединачног знања најбољих чланова групе.10 Овом техником се „убира знање“ давањем појединачних анонимних судова експерата о унапред постављеном питању, према строго дефинисаним правилима која истовремено омогућавају умањење утицаја негативних аспеката који проистичу из друштвених и професионалних односа међу члановима групе. 11

Делфи технику одликује релативна флексибилност у погледу методолошких захтева и препорука који се односе на начин спровођења истраживања. ${ }^{12}$ Уз $_{3}$

7 Sun Tzu, "The Art of War", Allandale Online Publishing, United Kingdom, 2000, p. 60.

8 RAND, Delphi Method, Available at: https://www.rand.org/topics/delphi-method.html (9.8.2020)

9 Ibid.

10 George Rowe et al., "The Delphi Technique: A Re-Evaluation of Research and Theory", Technological Forecasting and Social Change, Vol. 39, No. 3, 1991, p. 235.

11 Ibid., p. 236.

12 Овај став важи само за организацију целокупног истраживања. „Језгро“ делфи студије чини серија јасно структурисаних и повратном везом контролисаних одговора, о чему ће бити речи у наставку текста. 
неопходност поштовања базичних захтева и правила ове технике, могуће је прилагођавати број рунди, врсту упитника, начин обраде података и њихово тумачење, који би на најбољи начин обезбедили правилне одговоре на постављено истраживачко питање. Роy (George Rowe) и сарадници наводе анонимност, итерацију (понављање), контролисане повратне одговоре и статистичку агрегацију одговора групе као кључна методолошка обележја делфи метода. ${ }^{13}$ Они посебно истичу анонимност чланова групе као кључну претпоставку уклањања негативних последица које могу проистећи из односа међу члановима групе (статусних, професионалних и слично). ${ }^{14}$

Мада у литератури постоје настојања да се техника методолошки што више систематизује, неколико препрека угрожава таква настојања. ${ }^{15}$ Први разлог непотпуне систематизације јесте проблем у вези са прикупљањем података. Делфи се може спровести као квантитативна и квалитативна (у извесним случајевима и као комбинована) техника, тако да је готово немогуће дати уједначене препоруке за систематично прикупљање, синхронизацију обраде и тумачење података. Врста делфи технике диктира тип упитника и ниво његове структурисаности; у случају квалитативног истраживачког дизајна упитник је мање структурисан, док је код квантитативних делфи студија упитник карактерише ригидност у погледу њене структурисаности. Немогућности методолошке систематизације доприноси и чињеница да синтезе које се повратно шаљу експертима након рунди нису исте у квалитативном и квантитативном моделу. Пратећи мањи степен структурисаности упитника, повратни одговори који се достављају у квалитативним делфи студијама знатно су обимнији. Квантитативни извештаји који се достављају након рунде експертима садрже дескриптивну статистику, која описује групне одговоре добијене у претходној рунди и краћи коментар истраживача у вези са таквим налазом. На крају, последња препрека систематизацији делфи метода тиче се њене спроводљивости у оквиру великог броја научних дисциплина, попут медицине, здравствене неге, образовања и управљања производним процесима. Због тога је тешко идентификовати јединствена правила која би била примењена трансдисциплинарно.

Илустрација 1. Ток делфи студија

13 George Rowe et al., "The Delphi Technique: A Re-Evaluation of Research and Theory", Technological Forecasting and Social Change, Vol. 39, No. 3, 1991, p. 237.

14 Ibid.

15 у методолошкој литератури о делфи студијама аутори избегавају да говоре о тврдим препорукама већ радије систематизују постојећа истраживања у одређеним областима и представљају принципе на којима ваља спровести делфи студије. О принципима делфи студије видети више у: Gene Rowe \& George Wright, „The Delphi technique as a forecasting tool: issues and analysis“, International Journal of Forecasting, Vol. 15, No. 4, 1999, pp. 353-375; Catherine Powell, „The Delphi technique: myths and realities“, Journal of advanced nursing, Vol. 41, No. 4, 2003, pp. 376-382. 


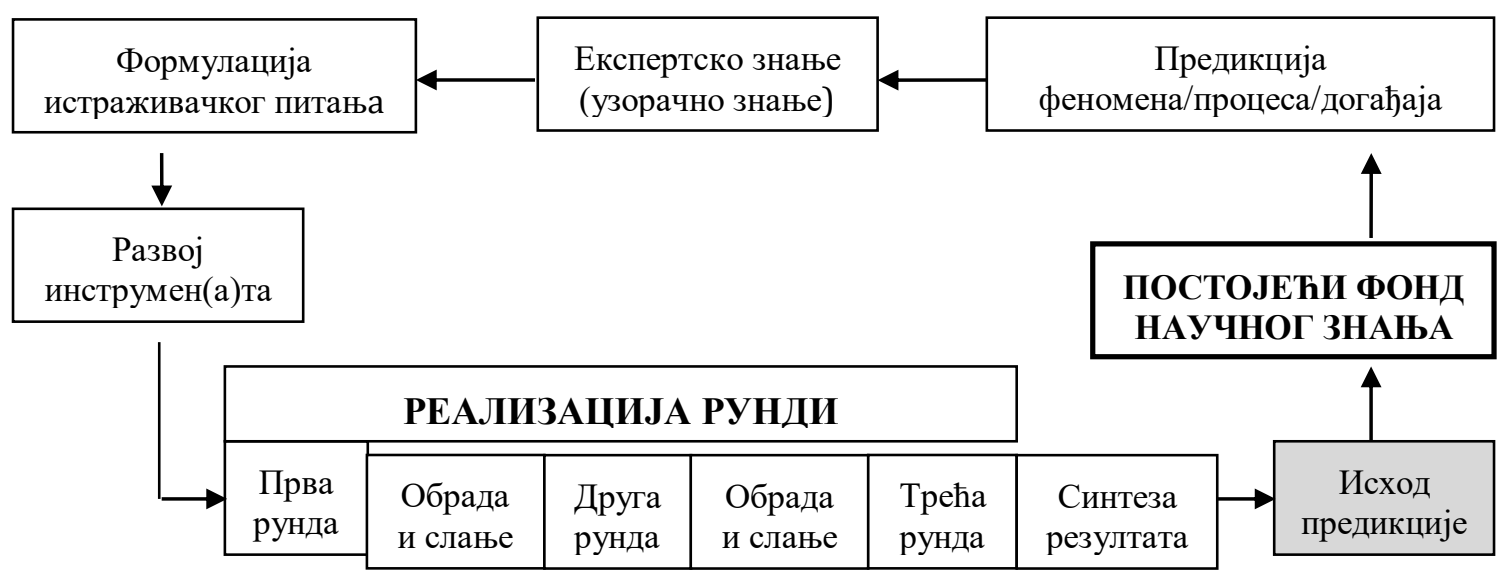

Извор: Аутор

У наставку ће бити приказан преглед најзначајнијих сегмената на које истраживачи треба да обрате пажњу приликом организовања и спровођења истраживања, а потом ће бити анализирана могућност плодотворног коришћења делфи технике у истраживањима феномена стратешких студија. Сегменти који су важни у организовању делфи студије односе се на избор експерата, величине групе, прецизирања инструмената, броја рунди, прикупљања и анализирања података и представљање резултата.

У општем смислу, делфи је подврста групног интервјуа који се спроводи у стриктно контролисаним и унапред дефинисаним условима. Учесници делфи студије морају бити експерти и група мора бити конзистентна у погледу броја и састава све време спровођења истраживања. Не постоји јединствена препорука о довољном броју учесника групе, тако да он најчешће варира. У највећем броју случајева, код хомогене групе, довољан број учесника је између 5 и 20.16 Армстронг (Scott Armstrong) сугерише да група треба да броји између 7 и 15 учесника. ${ }^{17}$ Величина групе није значајна уколико је број њених учесника већи од 5. Са друге стране, уколико је група превелика, то може довести до непотребног увећања аргументације и губљења правца којим сесије треба да се одвијају. Због тога се препоручује да групе буду сразмерне, колико год је то могуће, истраживаном проблему како би дискусија и потенцијални налази били адекватни. У истраживању спроведеном 1982. године, Давид Боје (David Boje) и Кејт Мурнинген (Keith Murninghan) установили су да величина групе у итеративним облицима доношења одлука није од суштинског значаја за исход и

16 Rowe, Gene, and George Wright, „Expert opinions in forecasting: the role of the Delphi technique“, Principles of forecasting, Springer, Boston, MA, 2001, p. 128.

17 Scott Armstrong, Long range forecasting: From Crystal Ball to Computer, John Wiley \& Sons, New York, 1985, p. 38. 
статистичку стабилност резултата. ${ }^{18}$ Норма Рејд (Norma Reid) примећује да величина групе може да варира између 10 и чак 1000 чланова.19 Чини се да је усамљен став према ком величина групе ипак утиче на исходе групног одлучивања, али је такав став изведен из студија у области медицине и природних наука генерално. ${ }^{20}$

Важан критеријум приликом одабира чланова групе тиче се задовољавања критеријума „експерта“. Питање експерта увек је спорно са аспекта квалитета групе као целине која треба да обави задатак предвиђања. Катарина Пауел (Catherine Powell) сугерише да експерте треба бирати према њиховим потврђеним квалификацијама, доприносу и кредибилитету у области у оквиру које се спроводи истраживање.21 Хетерогеност групе се препоручује као методолошка предност јер се у дискусију укључује обимнији ниво знања и искустава оних који га преносе. Последично, добијају се квалитативно дубљи и обухватнији увиди, а у случају статистичких студија прецизнији налази са мањом статистичком грешком. ${ }^{22}$

Идеално хомогену групу готово је немогуће оформити, иако је то један од принципа на којима се заснива делфи. Чак у случају одабира експерата са потпуно истим афилијацијама, међу њима ће увек постојати разлике у погледу њихових знања, искуства и перцепције феномена који представља(ју) део истраживачког питања. У литератури су, на бази богате истраживачке праксе, идентификоване улоге које експерти добијају након итерација. 23 Као могући модел продубљеног разумевања добијених налаза и разлика у одговорима поједини аутори диференцирају учеснике сесија на „прелетаче“ (swingers) и „издржљивце“ (holdouts). Прелетачи због своје несигурности и мањка искуства (потенцијално и нивоа знања и интересовања за са́мо истраживање) из рунде у рунду мењају свој став. Међутим, модификација ставова у рундама која није драстична, а која је настала под утицајем преференци остатка групе је пожељна и помаже нијансирању квалитета коначног исхода делфи сесије. Са друге стране,

18 David Boje \& Keith Murnighan, "Group confidence pressures in iterative decisions", Management Science, Vol. 28, No. 10, 1982, pp. 1187-1196.

19 Reid, Norma. "The Delphi technique: its contribution to the evaluation of professional practice“, Professional competence and quality assurance in the caring professions, 1988, p. 262.

20 Видети више у: Murphy, M. K., et al., „Consensus development methods, and their use in clinical guideline development", Health technology assessment, Vol.2, No. 3, 1998, pp. 1-88.

${ }^{21}$ Catherine Powell, „The Delphi technique: myths and realities“, Journal of advanced nursing, Vol. 41, No. 4, 2003, p. 379.

22 Gene Rowe and George Wright, Ibid, p. 128.

23 Важно је нагласити да ове улоге ни на који начин не нарушавају резултате и исходе појединачних рунди, нити делфи технике у целини. Улоге се посматрају као механизам за разумевање функционисања групе и из њих произилази продубљеније разумевање добијених одговора из сваке рунде. 
издржљивци пружају конзистентне одговоре из рунде у рунду и не мењају своје ставове под утицајем групе. ${ }^{24}$

Идеално типски „тачан“ одговор који група треба да достигне (Т) у највећем броју случајева се разликује од консензуса групе (median - “M"). Претпоставка да ће агрегат више одговора пружити супериорнији увид у односу на појединачне ставове, „помера“ скалу „тачног одговора“ ка средини скале могућих одговора, док ће, природно, консензус групе да се значајније помери од „Т“ позиције у случају занемаривања идеалног одговора од стране учесника групе. Развој инструмента је следећа важна специфичност у спровођењу делфи технике. Врста упитника зависи од тога да ли се делфи користи као квалитативна или квантитативна техника. Једна од најзначајнијих методолошких препорука тиче се истоветности инструмента у свим рундама. ${ }^{25}$ Ово нарочито важи у случају истраживања у којима се тражи квантитативно изјашњавање експерата. Тако обезбеђена конзистентност питања омогућава њихово адекватно статистичко поређење и тестирање стабилности одговора добијених у различитим рундама. Додатно, такво тестирање (о ком ће речи бити у наставку текста) од пресудне је важности за обустављање итерација и статистичку потврду стабилности исказа. Код квантитативно спроведене делфи студије потребно је да упитник буде постављен тако да мери вредносни суд учесника студије у вези са појединачним појавама, индикаторима, догађајима или вероватноћама. Због тога је потребно користити петостепену или седмостепену Ликертову скалу. Алтернативно, могуће је понудити експертима да на скали од 1 до 10 оцене значај одређеног проблема.

Након што је оформљена група експерата спремних да учествују у истраживању, одређено истраживачко питање и на бази њега састављен адекватан упитник, стичу се услови за покретање делфи студије. У литератури се препоручује да прва рунда буде мање структурисана у односу на остале рунде. 26 У смислу обухвата питања, прва рунда треба да има за циљ елиминацију непотребних одговора које је понудио истраживач и рангирање преференци према средишном одговору. У том случају прва рунда служи као својеврсна припрема за остале рунде. Уколико се спроводи квалитативни интервју, истраживач је у обавези да поред увида које добије од експерата, такође у упитнику понуди могуће алтернативе и опције које ће експерти својим изјашњавањем да „филтрирају“.

${ }^{24}$ Gene Rowe and George Wright, "The impact of task characteristics on the performance of structured group forecasting techniques", International Journal of Forecasting, Vol. 12, No. 1, 1996, pp. 83.

25 Под истоветношћу инструмента се подразумева централни део упитника који садржи питања која су његова окосница. Питања попут квалитативних одговора у вези са оценом квалитета упитника, додавања нових могућих одговора и слично могу варирати и ни на који начин не умањују истоветност инструмента.

26 Осим тога, важно је имати у виду да структурисаност упитника ни у ком случају не сме да буде угрожена. Видети више у: Gene Rowe \& George Wright, „The Delphi technique as a forecasting tool: issues and analysis“, International Journal of Forecasting, Vol. 15, No. 4, 1999, p. 367. 
Након сваке рунде истраживач врши сумаризацију одговора, након чега свим експертима доставља извештај. Извештај рунде је по свом садржају веома специфичан. Најпре, његова форма мора бити истоветна кроз све три (или више) рунди. ${ }^{27}$ Исти или сличан формат извештаја олакшаће експертима праћење сопственог и групног гласања и на тај начин ће најадекватније моћи да модификују своје одговоре уколико сматрају да за тим има потребе. Друга специфичност извештаја јесте оријентација ка експерту. Извештаји имају двојаку функцију: да прикажу преференце групе, али и преференце сваког појединачног експерта. Одступање појединачног од групног гласања јесте срж сваког извештаја и зато је важно у том сегменту посветити највећу пажњу како би се што веродостојније пренели исходи гласања.

Друга рунда је заправо „прва права“ рунда јер су пре ње извршене све „припремне“ радње које се тичу дефинисања узорка проблема о ком/којима се расправља. Истраживачи морају да буду сигурни да су се експерти упознали са извештајем из прве рунде јер ће њихово изјашњавање бити валидно једино у том случају. Након друге рунде, експертима се састављају нови извештаји, у којима се на сличан начин као и након прве рунде представљају преференце групе (из друге али и из обе рунде), као и појединачна одступања чланова у односу на преференце. У литератури не постоје упутства у вези са остављањем могућности експертима да допуне појаве/питања/проблеме у вези са којима се спроводи истраживање. ${ }^{28}$

У највећем броју случајева трећа рунда представља кулминацију спровођења делфи технике. Уколико је ова рунда последња, тада се не израђују појединачни извештаји, већ само један, интегрални преглед преференци групе, који се доставља експертима на увид. Након треће (или последње) рунде, експертима се обавезно саопштавају опште информације о структури групе које се тичу броја учесника, њихових афилијација, области експертизе и слично. У идеалним условима експерти након последње рунде попуњавају још један упитник у ком се

27 Препоручена форма извештаја треба да садржи информације о називу пројекта, врсти истраживања, администратору делфи студије (истраживачу), датуму спровођења рунде, датуму израде извештаја, иницијалнима експерта и броју рунде. Поред тога, централни део извештаја се односи на сумаризацију одговора свих чланова групе из претходне рунде. Сви подаци који се приказују у извештају морају верно представљати преференце групе и зато је пожељно да структура извештаја буде што једноставнија (по могућству табеларна) и без непотребних детаља. У случају квантитативног истраживања, након табеларног сумарног приказа одговора експерата и краће статистичке анализе одступања, потребно је пружити кратак коментар који би олакшао разумевање извештаја и омогућио адекватнију модификацију ставова експерта у наредним рундама. Код квалитативних истраживања текстуални описи могу, због природе добијених увида, бити опширнији, при чему је важно одржати што јаснији формат извештаја (коришћењем категорија, кодирања, сврставања у групе и слично).

28 У случају квантитативног делфи метода, због потребе да се обезбеди конзистентност статистичког мерења, поређења и анализе налаза, потребно је избегавати додавање нових питања о којима се расправља. 
изјашњавају о квалитету сесија чији су учесници били, квалитету упитника, затим о налазима, а нарочито је пожељно да понуде могуће коментаре у вези са додатним тумачењем већ добијених налаза. 29 Све ово ће истраживачима омогућити још детаљније припреме завршних анализа. Због неструктурисаности рунде која следи иза последње, као и непостојања обавезе да се сви учесници делфи студије изјасне у вези са исходима делфи студије, ова (најчешће) четврта рунда јесте у одређеном смислу хибридна.

Питање потребног броја рунди за „обустављање“ студије заузима једно од централних места у расправама о делфи методу. У случају квантитативних делфи сесија такво питање је мање проблематично због постојања неколико статистичких тестова којима се утврђује поузданост (стабилност) одговора између рунди. Због значаја који је доказан у литератури о делфи студијама, потребно је користити један или сва три теста којима се проверава стабилност одговора учесника рунди: хи-квадрат (Chi square), Фишеров тест (Fisher's exact test) и Мек Немаров тест промене (McNemar's change test). Све три технике претпостављају постојање табела контингенције у којима се систематично уносе подаци добијени у различитим рундама. Пирсонов хи-квадрат $(\chi 2)$ представља статистичко одступање добијених од очекиваних налаза. 30 Фишеров егзактни тест је сличан хи-квадрату, с тим да претпоставља постојање „2х2“ табеле контингенције. Иако су налази добијени Фишеровим тестом статистички ваљанији, његова валидност је ограничена само у случају поређења варијабли чије су вредности исказане дихотомно. ${ }^{31}$

Код квалитативних делфи студија не постоје мерљиви начини који би истраживачима олакшали доношење одлуке у вези са обустављањем студије. Због тога се истраживачима саветује да обуставе делфи након сесије у којој је постигнут консензус који им омогућава даљу научну верификацију. Јарир Дајани (Jarir Dajani) и сарадници наводе да је итерација потребна докле год постоје питања у вези са којима група није достигла консензус.32 На бази добијених одговора у рундама, могуће је добити пет исхода: консензус, већински

29 Истраживачи не треба да инсистирају на обавезном учешћу у попуњавању упитника након што је делфи окончан, већ такво учешће у хибридној рунди треба да буде факултативно.

30 Иако је употреба хи-квадрата за тестирање нулте хипотезе довољан метод, у појединим статистичким приручницима се заступа теза о неопходној „накнадној контроли“ снаге резултата добијених хи-квадрат тестом. Због тога се сугерише коришћење Крамеровог "V" теста (Cramer's V test), који представља својеврсну корелацију између два сета података. Крамеров „V“ тест укључује резултате хи-квадрат теста, а тумачење добијених корелација је исто као у случају класичних корелација. О употреби Крамеровог "V" теста видети више y: Mary L. McHugh, "The chi-square test of independence", Biochemia medica, Vol. 23, No. 2, 2013, pp. 143-149.

31 Истраживачима се саветује да користе програме за процесирање података попут MS Office Excel, SPSS IBM, R, STATA.

32 Jarir Dajani et al., "Stability and agreement criteria for the termination of Delphi studies", Technological forecasting and social change, Vol. 13, No. 1, 1979, p. 83. 
доминантан став, биполарност, плуралитет мишљења, и потпуно неслагање. ${ }^{33}$ Дајани и сарадници сматрају да квалитативни делфи може бити обустављен уколико након треће рунде исход буде једногласност или уколико превладава став подржан од стране већине учесника. Трећа могућност је биполарност, која према њиховом виђењу у одређеним случајевима може бити довољна за окончање делфи студије (при чему треба имати у виду динамику добијања таквог исхода по рундама), док плуралитет ставова и потпуна неслагања доводе до обавезног понављања рунди. ${ }^{34}$

\section{СОФИСТИЦИРАЊЕ ПРЕДВИЪАЊА - АЛАТИ ВЕШТАЧКЕ ИНТЕЛИГЕНЦИЈЕ}

Алати вештачке интелигенције представљају методе чији се рад базира на сложеним статистичким алгоритмима и хардверским компонентама које могу да подрже захтеве софтвера. Такви алати су широко коришћени у економији (економетрији) за предвиђање финансијских кретања на тржиштима широм света, као и у области биомедицинског инжењерства. Логика алата вештачке интелигенције базира се на апроксимацији правилности које препознају у комплексним сетовима података - временским низовима (time series). Роб Кичин (Rob Kitchin) наводи да су комплексне серије података (Big Data), „огромне у обухвату, различите у варијабилности, међусобно повезане у својој природи и флексибилне у смислу проширења, додавања нових варијабли и слично“. 35

Постоје две претпоставке без којих алати вештачке интелигенције не би функционисали: значајна количина података систематизованих у временске низове и претходно дефинисана правила према којима се устројава процесирање података. Иако су „оспособљени“ да аутономно третирају велике скупове података, и неуронске мреже и машинско учење морају имати унапред задата правила према којима ће вршити процесирање података. Такви скупови правила потичу из теорије игара, која је обимно концептуализована у оквиру студија безбедности и стратешких студија. ${ }^{36}$

Две технике за предикцију које функционишу на бази вештачке интелигенције јесу неуронске/неуралне мреже (neural networks) и машинско учење (machine

33 У случају става који је подржан од стране већине, Дајани и сарадници захтевају да више од $50 \%$ одговора буде конзистентно.

34 Дајани и сарадници овако описан модел називају хијерархијским стаблом заустављања делфи студија.

35 Rob Kitchin, "Big data and human geography: Opportunities, challenges and risks", Dialogues in Human Geography, Vol. 3, No. 3, 2013, p. 262

36 Можда најзначајнији допринос развоју и аплицирању модела теорије игара пружио је амерички политиколог Буено де Мескита (Bueno de Mesquita). 0 теорији игара и могућој апликабилности на предикцију оружаних сукоба, видети више у: De Mesquita, Bruce Bueno, „Game theory, political economy, and the evolving study of war and peace“, American Political Science Review, Vol. 100, No. 4, 2006, pp. 637-642. 
learning). Неуронске мреже су математички модели који су инспирисани природним, биолошким неуронима. То значи да могу извршити апроксимацију било ког функционалног облика који карактерише временске серије. Временске серије у највећем броју случајева обухватају варијабле које се тичу датума одређене појаве (конфликта, интервенције, протеста...), интензитета, обележја, броја жртава, географске локације, дужине трајања, страна у сукобу и слично. Вилијам Ремус (William Remus) и Маркус 0`Конор (Marcus O`Conor) наводе својство универзалне апроксимације као важну одлику неуралних мрежа, што нуди малу вредност ако је појавни облик једноставан (нпр. линеарни). ${ }^{37}$ Они наводе пример симулационе студије, спроведене 1998. године, која је показала да су неуронске мреже дале упоредиве нивое модела који се уклапају у правилно одређене полиномске регресионе моделе. ${ }^{38}$ Теоретски, неуронске мреже требале би бити у стању да моделирају податке, али и традиционалне статистичке методе (регресију, корелацију), јер филтрирају значајне записе (у оквиру великих сетова података) који су релевантни за извођење предиктивних ставова. Неуралне мреже функционишу на неколико принципа на којима се базира уобичајено квантитативно предвиђање: наивни приступ, просечно кретање, експоненцијално равнање, пројекција трендова или линеарна регресија.

\section{Подаци}

Мод Боненфант (Maude Bonenfant) и сарадници наводе феномен „хиперсимболизације“ као нову реалност дигиталног света. Поменути процес означава активирање до скора пасивне улоге података, који сада преузимају асертивну улогу у стварању знања. ${ }^{39}$ Подаци више не служе да прикажу људско знање, већ као његова допуна, пошто комплексне серије података по свом обиму и садржају трансцендирају искуство људског (са)знања. 40 До података се не долази на једноставан начин, нарочито не у друштвеним наукама, чије појаве карактерише нелинеарност и специфичност на нивоу јединице анализе. Процесиране сирове информације, које су обимне у оквиру било које одређене дисциплине, филтрирају се кроз различите концептуалне обрасце који одговарају теоријским потребама, а резултат сваког филтера јесте „мањи али смислен скуп хомогених података“.41 Овакав поступак Дејвид Сингер (David Singer) назива „креирањем података“ (data-making) и разликује га од простог уочавања

\footnotetext{
37 William Remus and Marcus O'Connor, „Neural networks for time-series forecasting“, Principles offorecasting, Springer, 2001, pp. 245-256.

38 Ibid., p. 246.

${ }^{39}$ Bonenfant, Maude et al., "Affected Data: Understanding Knowledge Production in Algorithmic Events”, Global Media Journal, Vol. 11, No. 2, 2019, pp. 66-78.

${ }^{40}$ Ibid.

${ }^{41}$ Singer, David, "Data-making in international relations", Behavioral Science, Vol. 10, No. 1, 1965, pp. 68-80.
} 
чињеница (fact-finding).42 Подаци који би имали ингративни капацитет у приказу понашања државе на спољнополитичком плану (изјаве шефова држава и/или влада, активности министарстава спољних послова, деловање оружаних снага на стратешком нивоу) у великој мери су јавно доступни. Међутим, Сингер исправно примећује проблем који се јавља на херменеутичкој равни. Истраживач „преводи“ стварне интеракције онако како верује да треба, што последично доводи до лоше интерпретације и неадекватности налаза добијених управо анализом тих података. Како би пружили ваљане и прецизне резултате, алати вештачке интелигенције морају бити „храњени“ огромном количином података. Такви подаци су најчешће организовани у временске серије - низове, који су одређени као „хронолошки низ података који представља индикатор понашања разних појава током узастопних и једнаких временских интервала“.43 Кодификовани сетови података стога су важан извор грађе за плодотворан рад алата вештачке интелигенције, па ће у наставку бити приказано неколико система који раде на том принципу. 44

Интегрисани систем раног упозоравања на кризе (The Integrated Crisis Early Warning System - ICEWS) је свеобухватан, интегрисани и аутоматизовани систем за праћење, процену и прогнозу националних, субнационалних и унутрашњих криза. 45 Принцип на ком почива рад овог система базиран је на комбинованим методима за предвиђање нестабилности. Комбинујући хетерогене статистичке моделе у интегрисаном глобалном простору, овај систем функционише са укупном тачношћу прогнозе већом од 80 процената. ${ }^{46}$ Подаци се прикупљају у скоро реалном времену из више од 100 извора података и 250 међународних и регионалних информативних медијских кућа. ${ }^{47}$ Целокупан систем се састоји од четири конститутивна сегмента. Први обухвата изузетно сложену базу података (iData) која индексира преко 45 милиона вести на енглеском, шпанском, португалском и арапском језику од 1991. године до данас. Други сегмент система односи се на препознавање и визуелизацију података (iTrace) кроз конверзију вести у структурне индикаторе који осликавају особеност и интензитет догађаја. Трећи и уједно најкомплекснији сегмент система јесте предикција насилних догађаја (iCast) са прецизношћу предвиђања већом од 90\%. Овај сегмент

42 Ibid., p. 69.

43 Jovana Božić, Predikcija vremenskih nizova pomoću talasića i neuralnih mreža sa primenom za predikciju valutnih parova, Doktorska disertacija, Univerzitet Union, Beograd, 2017, str. 2.

44 Знатан пораст квантитативних студија отпочео је промоцијом и популаризацијом кодификованих серија података у области студија мира, студија безбедности и геополитике. Ова фаза је означена као друга етапа квантификације геополитике. Видети више у: Nenad Stekić, Nova paradigma kvantifikacije geopolitičkih pojava: interpretacije, metodi i izvori podataka, Međunarodni problemi, Vol. LXXII, br. 1, 2020, str. 222.

45 Integrated Crisis Early Warning System (ICEWS), 2020, Retrieved from: https://www.lockheedmartin.com/en-us/capabilities/research-labs/advanced-technologylabs/icews.html (20/08/2020)

46 Ibid.

47 Ibid. 
омогућава предикције на шестомесечном нивоу за 167 земаља у вези са догађајима од интереса: унутрашња политичка криза, међународна криза, етничко/религијско насиље, побуна, насилно рушење режима. За наведена три сегмента потребно је задовољити довољан степен аналитичког капацитета велике количине података. Због тога је последњи сегмент овог система (iSent) направљен тако да буде аналитички алат и служи као помоћ у приказу, филтрирању, процесирању и анализи података.

Пројекат прикупљања података о локацији и догађајима оружаних сукоба (Armed Conflict Location \& Event Data Project - ACLED) је база података која индексира варијабле о датуму, актерима, локацијама, људским жртвама и врстама свих пријављених политичких протеста и насилних окупљања широм Африке, Источне Азије, Јужне Азије, Југоисточне Азије, Блиског Истока, Централне Азије и Кавказа, Латинске Америке и Кариба, Источне Европе и Балкана. ${ }^{48}$ Пројекат ACLED такође спроводи истраживања у циљу израде анализа о природи сукоба, могућим сценаријима њиховог развоја (или гашења), а подаци из базе су јавно доступни и бесплатни за коришћење. ${ }^{49}$ Сличан овом, постоји још један пројекат, Глобална база догађаја, језика и тона (Global Database of Events, Language, and Tone - GDELT), која надгледа светске медије из готово свих крајева сваке земље у штампаним, емитованим и веб форматима на преко 100 језика у сваком тренутку.50 Подаци се протежу од 1. јануара 1979. до данас, а база података се састоји од четврт милијарде геореференцираних записа који покривају читав свет током 30 година. 51

Проблем са предикцијом тиче се одступања од уобичајених линераних вредности. Таква одступања нарушена су шумовима или такозваним „таласићима“ (wavelets).52 У науци о међународним односима сви феномени чије испољавање није могуће ни на који начин предвидети означавају се феноменом „црног лабуда“.53 Због тога су академска настојања за предикцијом малобројна, али веома

48 ACLED, About ACLED, 2020, Retrieved from: https://acleddata.com/about-acled $(22 / 08 / 2020)$

49 Подаци пројекта ACLED доступни су на: ACLED, Data Export Tool, 2020, Retrieved from: https://acleddata.com/data-export-tool (22/08/2020)

50 GDELT, The GDELT Story, 2020, Retrieved from: https://www.gdeltproject.org/about.html $(22 / 08 / 2020)$

51 Ibid.

52 За више студија којима се врши предикција појава попут оружаних сукоба, тероризма, војног наоружања и грађанских ратова, консултовати: Khalid, Usman, and Olivier Habimana. "Military spending and economic growth in Turkey: A wavelet approach." Defence and Peace Economics (2019): 1-15; Subramanian, Devika, and Richard J. Stoll. "Events, patterns, and analysis forecasting international conflict in the twenty-first century." Programming for Peace. Springer, Dordrecht, 2006. 145-160; Li, Ze, et al. "Terrorist group behavior prediction by wavelet transform-based pattern recognition." Discrete Dynamics in Nature and Society 2018 (2018).

53 Идеја о „црном лабуду“ преузета је из економије,а развио ју је економиста Николас Талеб, због чега је теза широко оспоравана у оквиру науке о међународним односима. 
успешна. Једно од најобухватнијих истраживања предикције оружаних сукоба учинили су Мучлински (Muchlinski) и сарадници. Они су коришћењем метода кластеризације и стабла хијерархије (random forest) успели да предвиде грађанске ратове са процентом тачности од 80\%.54 У истраживачком домену стратешких студија, неуронске мреже и машинско учење су први пут институционално примењени у оквиру пројекта VIEWS+, развијеног од стране истраживача са Универзитета у Упсали. Пројекат VIEWS+ је надградња претходне верзије VIEWS, који има за циљ предвиђање избијања насилних криза. Тренутно систем пружа рана упозорења за три облика политичког насиља: оружани сукоб који укључује државе и побуњеничке групе, оружани сукоб између недржавних актера и насиље над цивилима. 55

\section{УСЛОЖЊАВАЊЕ ГЛОБАЛНИХ ПРОЦЕСА И СТРАТЕШКОГ ДЕЛОВАЊА АКТЕРА НА ПОСТУПКЕ ПРЕДИКЦИЈЕ}

Још увек не постоје опсежне расправе у вези са одабиром техника за предвиђање појава стратешких студија. На бази претходно изнете анализе и прегледа, по обиму малобројне, релевантне академске литературе, могуће је издвојити четири дистинктивна обележја два метода. То су задаци употребе две технике, валидација сагласности, временски домет/домен предвиђања, и на крају, могућност научног уопштавања добијених налаза. Аутор верује да ова обележја могу представљати полазну основу и олакшати истраживачима и институцијама одабир адекватне технике, која би најплодотворније допринела сазнајним потребама.

Делфи студија у уско одређеном смислу служи за предикцију, што је и био њен првобитни задатак. Међутим, шире схваћено, делфи студија може допринети формулисању консензуса у вези са одређеним проблемом или истраживаном појавом post festum. Додатно, Ген Роу (Gene Rowe) и Џорџ Рајт (George Wright) наводе да је предвиђање само један од три могућа употребна облика делфи студија. Они идентификују формирање јавних политика и просуђивање о потребним задацима у случају дефицита информација о одређеној теми, као два додатна случаја када је подесно спровести делфи. 56 У оквиру стратешких студија делфи може имати значајну примену у развоју стратегија, дискусијама у погледу дефинисања спољнополитичких циљева, развоју безбедносне политике, доприносу у анализи понашања држава у међународним односима,

54 David Muchlinski et al., „Comparing random forest with logistic regression for predicting classimbalanced civil war onset data“, Political Analysis, Vol. 24, No. 1, 2016, pp. 87-103.

55 VIEWS, “About ViEWS”, 2020, Retrieved from: https://www.pcr.uu.se/research/views/aboutviews (22/08/2020)

56 Gene Rowe and George Wright, "The impact of task characteristics on the performance of structured group forecasting techniques", International Journal of Forecasting, Vol. 12, No. 1, 1996, p. 75. 
објективизацији сукоба, као и проценама утицаја ширег броја друштвених феномена који имају утицај на безбедност државе и њених грађана. Уколико се експертско знање користи зарад формулације секторских политика, попут спољне и/или безбедносне, тада се обавезно захтева валидација сагласности свих експерата који су учествовали у делфи студији, што није захтев који је потребан у случају предикције. ${ }^{57}$ Код алата вештачке интелигенције сама структура процеса обраде велике количине података према унапред утврђеним правилима представља својеврсну валидацију исхода који се тичу предвиђања и стога не захтева додатну „сагласност“ истраживача.

Временски домет/н предвиђања је једно од дистинктивних обележја. У случају делфи технике могуће је изводити средњорочна и чак дугорочна предвиђања за период од неколико деценија, што није могуће у случају алата вештачке интелигенције. Предикције у случају неуралних мрежа ће бити прецизније ако је домен предвиђања орочен на што краћи период. Тако најчешће се предикције изводе за период до шест месеци, а најдуже до годину дана. Аргументацију за употребу делфи технике у краткорочном предвиђању феномена у оквиру стратешких студија је тешко одбранити. Због тога не чуди став Јозефа Коута (Joseph Coates), који тврди да ову методу треба применити за краткорочна предвиђања само као „последње средство“ онда када није могуће извести адекватне моделе на бази статистичког предвиђања или других врста квалитативних података. 58

Могућност научне генерализације добијених налаза је, чини се, кључна дистинкција између поменута два метода предикције. Док је у случају делфи студије уопштавање добијених налаза готово немогуће јер је уско фокусирана на једну студију случаја, код алата вештачке интелигенције је могуће извести до одређене мере уопштавања зато што се предиктивни ставови о испољавању појаве састоје од група (кластера) које упућују на одређену (под)врсту појава. Тако је могуће изводити предиктивне ставове о испољавању побуна, протеста, ратова, грађанских ратова, промена режима и слично. Због тога, фактори који су идентификовани, а који се налазе у позадини предикције, могу се уопштавати као предиктори сличних или истих појава. Цедерман (Cedermann) и Вајдман (Weidmann) спадају у групу аутора који изражавају песимизам у погледу очекивања за предикцијом феномена из области стратешких студија. Они сматрају да су друштвени и политички процеси толико комплексни да је готово немогуће са извесношћу изводити предикционе ставове, али нуде препоруке за побољшање модела предикције. 59

57 Ibid., p. 75.

58 Coates, Joseph, "In defence of delphi: A review of delphi assessment, expert opinion forecasting, and group process by H. sackman", Technological Forecasting and Social Change, Vol. 7, No. 4, 1975, pp. 193-194.

59 Видети више у: Cederman, Erik \& Nils Weidmann, "Predicting armed conflict: Time to adjust our expectations?", Science, Vol. 355, No. 6, 2017, pp. 474-476. 


\section{ЗАКЉУЧНА РАЗМАТРАЊА}

Истраживачко поље стратешких студија је плодотворно за развој метода помоћу којих се могу вршити апроксимације будућих дешавања, предвиђати интензитет испољавања појава - оружаних сукоба, преврата, грађанских ратова, као и формулисање секторских политика у области безбедности и одбране. Нелинеарност испољавања друштвених појава и процеса онемогућава усавршавање предиктивних модела у случају алата вештачке интелигенције, али су зато драстично поузданији у погледу количине података које могу да обраде. Са друге стране, знање експерата омогућава извођење ставова о будућим појавама на бази аргумената који проистичу из њиховог искуства. Како обе технике имају мањкавости, њихова комплементарна употреба отклања појединачне недостатке. Управо зато је овај рад представио два доминантна метода за предикцију експертско знање и алате вештачке интелигенције, позивајући истовремено на њихову могућу популаризацију у оквиру истраживачких пројеката у стратешким студијама. Аутор је указао на могућност коришћења делфи технике као једног од најефикаснијих метода групног консензуалног одлучивања. Делфи техника може бити коришћена при формулисању стратешких аката и политика у области војне безбедности, али и у предикцији појединих догађаја или процеса, што може значајно користити доносиоцима одлука у сфери спољне и безбедносне политике. Висока структурисаност делфи технике и експертиза учесника панела генеришу валидне, и за научно знање релевантне увиде, који представљају значајну допуну објашњењу појединих феномена. Са друге стране, истраживачи стално морају имати у виду неколико „замки“ делфи студија које би им омогућиле адекватнос планирање истраживања. Потенцијална манипулација повратним информацијама експертима између рунди, превелико апострофирање значаја делфи метода у предикцији, доминантно изражена субјективност експерата који учествују у панелу и симплификација веома сложених процеса који ће се дешавати у будућности, само су неки од проблема који су и даље присутни у већини делфи студија. 60 Алати вештачке интелигенције захтевају интердисциплинарна научна знања, јер је осим експертизе у области стратешких студија за разумевање сложених алгоритама потребно и разумевање статистичких принципа и информатике.

Развој групних техника за консензуално одлучивање и софистицирање софтверских модела вештачке интелигенције за предвиђање, свакако представљају својеврсни одговор замерци која је упућена стратешким студијама, а која се тицала „псеудонаучности“ метода које користи. Наиме, Хедли Бул је пре неколико деценија систематизовао групу критика упућених на рачун теорије

60 О осам „замки“ делфи студија и детаљном прегледу проблема који проистичу из употребе овог метода видети више у: Harold Linstone, “Eight Basic Pitfalls: A checklist”, in: Harold Linstone, Murray Turof and Olaf Helmer (eds.), The Delphi Method Techniques and Applications, Portland State University and University of Southern California, 2002, pp. 559571. 
игара, системске анализе, симулација и сценарија као метода који не испуњавају критеријум научности јер су „лажни и пружају произвољну и субјективну слику у процесу доношења стратешких одлука“.61 Међутим, таква теза би тешко могла бити брањена у условима савремених технолошких решења која рационализују праксу доношења одлука у области безбедности и одбране.

\section{БИБЛИОГРАФИЈА}

1. ACLED, About ACLED, Retrieved from: https://acleddata.com/about-acled (22/08/2020).

2. ACLED, Data Export Tool, Retrieved from: https://acleddata.com/data-export-tool $(22 / 08 / 2020)$.

3. Armstrong, Scott, "Findings from evidence-based forecasting: Methods for reducing forecast error", International Journal of Forecasting, Vol. 22, No. 3, 2006, pp. 583598.

4. Armstrong, Scott, Long range forecasting: From Crystal Ball to Computer, John Wiley \& Sons, New York, 1985.

5. Ayson, Robert, "Strategic Studies", In: Christian Reus-Smit and Duncan Snidal (eds), The Oxford Handbook of International Relations, 2008, pp. 558-575

6. Boje, David \& Murnighan, Keith, "Group confidence pressures in iterative decisions", Management Science, Vol. 28, No. 10, 1982, pp. 1187-1196.

7. Bonenfant, Maude et al., "Affected Data: Understanding Knowledge Production in Algorithmic Events", Global Media Journal, Vol. 11, No. 2, 2019, pp. 66-78.

8. Bull, Hedley, "Strategic studies and its critics", World Politics, Vol. 20, No. 4, 1967, pp. 593-605.

9. Catherine Powell, „The Delphi technique: myths and realities“, Journal of advanced nursing, Vol. 41, No. 4, 2003, pp. 376-382.

10. Coates, Joseph, "In defence of delphi: A review of delphi assessment, expert opinion forecasting, and group process by H. Sackman", Technological Forecasting and Social Change, 1975, pp. 193-194.

11. Integrated Crisis Early Warning System (ICEWS), Retrieved from: https://www.lockheedmartin.com/en-us/capabilities/research-labs/advancedtechnology-labs/icews.html (20/08/2020)

12. Jarir Dajani et al., "Stability and agreement criteria for the termination of Delphi studies", Technological forecasting and social change, Vol. 13, No. 1, 1979, pp. 8390.

13. Khalid, Usman, and Olivier Habimana. "Military spending and economic growth in Turkey: A wavelet approach", Defence and Peace Economics, Vol. 19, No. 1, 2019, pp. 1-15.

14. Li, Ze, et al. "Terrorist group behavior prediction by wavelet transform-based pattern recognition", Discrete Dynamics in Nature and Society, Vol. 10, No. 1, 2018

${ }^{61}$ Hedley Bull, "Strategic Studies and its Critics", World Politics, Vol. 20, No. 4, (July 1968), p. 601. 
15. Linstone, Harold, "Eight Basic Pitfalls: A checklist”, in: Harold Linstone, Murray Turof and Olaf Helmer (eds.), The Delphi Method Techniques and Applications, Portland State University and University of Southern California, 2002, pp. 559-571.

16. Mary L. McHugh, "The chi-square test of independence", Biochemia medica, Vol. 23, No. 2, 2013, pp. 143-149.

17. Murphy, M. K., et al., „Consensus development methods, and their use in clinical guideline development", Health technology assessment, Vol.2, No. 3, 1998, pp. 1-88.

18. Nenad Stekić, Nova paradigma kvantifikacije geopolitičkih pojava: interpretacije, metodi i izvori podataka, Međunarodni problemi, Vol. LXXII, br. 1, 2020, str. 215235.

19. Noor, K. B. M. (2008). Case study: A strategic research methodology. American journal of applied sciences, 5(11), 1602-1604.

20. Rob Kitchin, "Big data and human geography: Opportunities, challenges and risks", Dialogues in Human Geography, Vol. 3, No. 3, 2013, p. 262-277.

21. Rowe, Gene \& Wright, George, The Delphi technique as a forecasting tool: issues and analysis, International Journal of Forecasting, Vol. 15, No. 4, 1999, pp. 353-375.

22. Rowe, Gene and George Wright, "The impact of task characteristics on the performance of structured group forecasting techniques", International Journal of Forecasting, Vol. 12, No. 1, 1996, pp. 73-89.

23. Rowe, George et al., "The Delphi Technique: A Re-Evaluation of Research and Theory", Technological Forecasting and Social Change, Vol. 39, No. 3, 1991, pp. 235251.

24. Subramanian, Devika and Stoll, Richard, "Events, patterns, and analysis forecasting international conflict in the twenty-first century", Programming for Peace, Springer, Dordrecht, 2006, pp. 145-160.

25. Sun Tzu, "The Art of War”, Allandale Online Publishing, United Kingdom, 2000

26. Ward, Michael, „Can we predict politics? Toward what end?“, Journal of Global Security Studies, Vol. 1, No. 1, 2016, pp. 80-91.

27. Singer, David, "Data-making in international relations", Behavioral Science, Vol. 10, No. 1, 1965, pp. 68-80.

28. Bull, Hedley, "Strategic Studies and its Critics", World Politics, Vol. 20, No. 4, (July 1968), pp. 593-605.

29. Remus, William and O'Connor, Marcus, „Neural networks for time-series forecasting“, Principles of forecasting, Springer, 2001, pp. 245-256.

30. Muchlinski, David et al., "Comparing random forest with logistic regression for predicting class-imbalanced civil war onset data", Political Analysis, Vol. 24, No. 1, 2016, pp. 87-103.

31. Cederman, Erik \& Weidmann, Nils, "Predicting armed conflict: Time to adjust our expectations?”, Science, 355(6324), 2017, pp. 474-476.

32.VIEWS, "About ViEWS", 2020, Retrieved https://www.pcr.uu.se/research/views/about-views (22/08/2020)

33. De Mesquita, Bruce Bueno, „Game theory, political economy, and the evolving study of war and peace", American Political Science Review, Vol. 100, No. 4, 2006, pp. 637642. 


\section{PREDICTING STRATEGIC STUDIES PHENOMENA: COULD DELPHI TECHNIQUE AND ARTIFICIAL INTELLIGENCE TOOLS HELP?}

In the scientific-cognitive sense, the prediction, as one of the scientific goals, is in most cases a relatively unattainable activity. Prediction's limitations are especially visible in the study of social phenomena whose phenomenology is characterized by a high degree of variability and irregularities. The expansion of the research agenda of strategic studies imposes the need for increasingly frequent complex analyses with the task of providing possible outlines of the development of individual events or processes in the future. The subject of strategic studies is, therefore, naturally time-oriented to the current reality and future occurrences. This paper aims to present two groups of tools on the researchers' disposal, in the prediction of phenomena within strategic studies. The academic literature abounds with arguments that make the prediction of possible violations of military security by the outbreak of armed conflicts the dominant goal of strategic studies. Consequently, the subject of this paper includes a presentation of two groups of techniques that are most used in the analysis and prediction of armed conflicts: expert knowledge and artificial intelligence tools. Each of the groups of techniques is characterized by specifics and limitations in performing predictive attitudes. The author will refer to the range of prediction techniques based on the knowledge of experts - delphi techniques. Within the tools of artificial intelligence, the possibilities of analysis arising from the process of Machine Learning and Neural Networks will be presented. Although data and IT tools are undoubtedly dominant in innovating the way of analyzing previous and predicting future phenomena, the importance of expert knowledge obtained on the basis of group decision making should not be neglected.

Keywords: strategic studies, Delphi technique, machine learning, neural networks, artificial intelligence, prediction, armed conflicts 